\title{
Bacteroides cellulosolvens sp. nov., a Cellulolytic Species from Sewage Sludge $\dagger$
}

\author{
WILLIAM D. MURRAY,* L. C. SOWDEN, AND J. ROSS COLVIN \\ Division of Biological Sciences, National Research Council of Canada, Ottawa, Canada KIA OR6
}

\begin{abstract}
A new mesophilic, cellulolytic species of Bacteroides was isolated from a methanogenic cellulose enrichment culture of municipal sewage sludge and is described. This species ferments only cellulose and cellobiose. The fermentation products are acetic acid, $\mathrm{CO}_{2}, \mathrm{H}_{2}$, ethanol, and small amounts of lactic acid. The deoxyribonucleic acid base composition is 43 mol\% guanine plus cytosine. The name Bacteroides cellulosolvens is proposed. Type strain WM2 is deposited in the National Research Council of Canada culture collection as strain NRCC 2944.
\end{abstract}

A mesophilic coculture consisting of a cellulolytic anaerobe and a saccharolytic anaerobe was isolated from a cellulose enrichment culture started from municipal sewage sludge. These two anaerobes grew on cellobiose agar as a single, slimy colony (6). The saccharolytic member of this coculture, Clostridium saccharolyticum, has been isolated and described previously (13). In this paper, we describe the isolation and characteristics of the cellulolytic microbe and propose for it the name Bacteroides cellulosolvens.

\section{MATERIALS AND METHODS}

Media. The basal medium used for isolation and maintenance of the strain which we studied had the following composition (in milligrams per liter); $\mathrm{NaHCO}_{3}, 2,000$; $\mathrm{NH}_{4} \mathrm{Cl}, 680 ; \mathrm{K}_{2} \mathrm{HPO}_{4}, 296 ; \mathrm{KH}_{2} \mathrm{PO}_{4}, 180 ;\left(\mathrm{NH}_{4}\right)_{2} \mathrm{SO}_{4}, 150 ;$ $\mathrm{MgSO}_{4} \cdot 7 \mathrm{H}_{2} \mathrm{O}, 120 ; \mathrm{CaCl}_{2} \cdot 2 \mathrm{H}_{2} \mathrm{O}, 61 ; \mathrm{FeSO}_{4} \cdot 7 \mathrm{H}_{2} \mathrm{O}, 21$; $\mathrm{N}\left(\mathrm{CH}_{2} \mathrm{COOH}\right)_{3}, 15 ; \mathrm{NaCl}, 10 ; \mathrm{MnSO}_{4} \cdot \mathrm{H}_{2} \mathrm{O}, 5 ;$ $\mathrm{CoCl}_{2} \cdot 6 \mathrm{H}_{2} \mathrm{O}, 1 ; \mathrm{ZnSO}_{4} \cdot 7 \mathrm{H}_{2} \mathrm{O}, 1 ; \mathrm{CuSO}_{4} \cdot 5 \mathrm{H}_{2} \mathrm{O}, 0.1$; $\mathrm{AlK}\left(\mathrm{SO}_{4}\right)_{2} \cdot 12 \mathrm{H}_{2} \mathrm{O}, 0.1 ; \mathrm{H}_{3} \mathrm{BO}_{3}, 0.1 ; \mathrm{Na}_{2} \mathrm{MoO}_{4} \cdot 2 \mathrm{H}_{2} \mathrm{O}, 0.1$; pyridoxine hydrochloride, 0.1 ; thiamine hydrochloride, 0.05 ; riboflavin, 0.05; nicotinic acid, 0.05 ; $p$-aminobenzoic acid, 0.05 ; lipoic acid, 0.05 ; biotin, 0.02 ; folic acid, 0.02 ; vitamin $\mathrm{B}_{12}, 0.005$; and resazurin, $1(7)$. This medium was prepared by the procedure of Holdeman et al. (3) and was prereduced by the Hungate technique (5), using $250 \mathrm{mg}$ of cysteine hydrochloride per liter and $250 \mathrm{mg}$ of $\mathrm{Na}_{2} \mathrm{~S} \cdot 9 \mathrm{H}_{2} \mathrm{O}$ per liter as the reducing agents. The reduced medium was dispensed under $80 \% \mathrm{~N}_{2}-20 \% \mathrm{CO}_{2}$ in $10-\mathrm{ml}$ amounts into $60-\mathrm{ml}$ serum vials (11) containing preweighed amounts of insoluble substrates, such as cellulose. The vials of media were then autoclaved at $104 \mathrm{kPa}$ for $15 \mathrm{~min}$. The soluble substrates were filter sterilized and were injected by means of hypodermic syringes into the basal medium after the vials had been autoclaved and cooled. The final $\mathrm{pH}$ of all media was $7.0 \pm$ 0.2 . The isolated strain was maintained at $35^{\circ} \mathrm{C}$ in basal medium containing approximately $0.5 \%(\mathrm{wt} / \mathrm{vol})$ cellulose in the form of small squares of 4-ply facial tissue.

Isolation. All isolation procedures were conducted anaerobically in serum vials or in an anaerobic chamber.

Biochemical tests. The procedures of Holdeman et al. (3) were used for biochemical characterization. Selected substrates were added to the basal medium at concentrations of $1 \%(\mathrm{wt} / \mathrm{vol})$. When a test required the addition of a fermentable substrate (e.g., sulfate reduction medium), $0.5 \%$ cellobiose was used. The test media were inoculated with $0.05 \mathrm{ml}$ of

\footnotetext{
* Corresponding author.

† National Research Council of Canada paper 23165.
}

a 72-h-old culture grown in cellulose broth and were incubated at $35^{\circ} \mathrm{C}$. Media containing cellulose were incubated on a rotary shaker. Test results were determined after $72 \mathrm{~h}$ and 7 days. Negative tests were held for 4 weeks. Metabolic products were quantified by gas chromatography. Gas volume was measured with a gas manometer, and the gas composition $\left(\mathrm{N}_{2}, \mathrm{CO}_{2}\right.$, and $\left.\mathrm{H}_{2}\right)$ was determined by gas chromatography, using the method of van Huyssteen (16). Alcohols and volatile acids were assayed by the method of Ackman (1), and nonvolatile acids were methylated by the procedure of Holdeman et al. (3) before determination by gas chromatography.

Temperature and $\mathrm{pH}$ studies. Temperature and $\mathrm{pH}$ ranges and optima were determined in cellobiose broth. Growth was measured spectrophotometrically at $650 \mathrm{~nm}$ in cuvettes with a $1-\mathrm{cm}$ light path.

Electron micrographs. For electron microscopy, cells were diluted in distilled water, placed on Formvar films, and dialyzed overnight. The films were then placed on carboncoated grids, shadowed with Pt-Pd, and observed with a Siemens model 101 electron microscope.

DNA base composition. The deoxyribonucleic acid (DNA) was isolated and purified by the Marmur method (9) from cells grown for $72 \mathrm{~h}$. The DNA base composition was determined by ultraviolet spectroscopy, using the method of Ulitzer (15). Escherichia coli, Bacillus subtilis, and salmon sperm DNAs, which had guanine-plus-cytosine contents of $51,42.5$, and $44.4 \mathrm{~mol} \%$, respectively, were used as standards.

\section{RESULTS AND DISCUSSION}

Cellulolytic strain WM2 ${ }^{\mathrm{T}}$ ( $\mathrm{T}=$ type strain) was obtained in pure culture by penicillin counterselection. The failure of conventional techniques to separate the cellulolytic anaerobe from $C$. saccharolyticum was presumed to be due to the slimy nature of the symbiotic coculture (6). However, the cellulolytic microbe did not grow in glucose-yeast extract medium and, unlike $C$. saccharolyticum, was not affected by the action of penicillin. Basal medium containing $1 \%$ glucose and $1 \%(\mathrm{wt} / \mathrm{vol})$ yeast extract was inoculated with a coculture and incubated at $35^{\circ} \mathrm{C}$ for $2 \mathrm{~h}$ before penicillin $\mathrm{G}$ was added at a concentration of $0.5 \mathrm{mg} / \mathrm{ml}$. This initial $2-\mathrm{h}$ incubation period allowed the cellulolytic species time to exhaust its endogenous energy reserves and cease growth. After $24 \mathrm{~h}$ of incubation the cells were washed free of penicillin. Dilutions were spread onto basal agar medium containing $1 \%$ cellobiose, and the cultures were incubated at $35^{\circ} \mathrm{C}$ until colonies were visible. Colonies were picked and 
replica-plated on cellobiose agar and glucose-yeast extract agar. Colonies which grew on cellobiose agar but not on glucose-yeast extract agar were found to be free of the contaminating $C$. saccharolyticum.

Strain $\mathrm{WM}^{\mathrm{T}}$ is an anaerobic, gram-negative, nonsporeforming, nonmotile, rod shaped organism which produces acetic acid as its major metabolic product and appears to belong in the genus Bacteroides. The morphological and biochemical characteristics of strain $\mathrm{WM} 2^{\mathrm{T}}$ do not match the characteristics of any of the species listed previously in the genus Bacteroides $(3,4)$. Therefore, we propose the establishment of a new species, Bacteroides cellulosolvens (cell. u.lo.sol'vens. L. v. solvere to dissolve; N.L. adj. cellulosolvens cellulose dissolving), so named because of its ability to ferment cellulosic substrates.

The cells are straight, rod-shaped, approximately 0.8 by 6 $\mu \mathrm{m}$, and occur singly. They are nonmotile, and no flagella are detected by staining (10) or electron microscopy. Extensions of the cell wall give this microbe a distinctive rough amorphous appearance when it is grown on insoluble cellulosic substrates (Fig. 1). An ultrastructure study has shown that these projections are extensions of the cell wall rather than capsular material. The projections do not occur when the organism is grown in cellobiose broth. Thin crosssections show the typical tripartite cell wall structure of gram-negative aerobes.

Spores are not demonstrated by malachite green staining of 1-week-old cultures or by treatment of cultures with $50 \%$ ethanol for $1 \mathrm{~h}(8)$. Cultures grown in facial tissue broth that are 2 days old are still viable after being held for $10 \mathrm{~min}$ at temperatures up to $75^{\circ} \mathrm{C}$; however, heat tolerance decreases with culture age.

Bright yellow, circular, convex colonies with rough margins are produced on cellobiose agar. The colonies reach a maximum diameter of 1.0 to $1.25 \mathrm{~mm}$ after 5 days of growth at $35^{\circ} \mathrm{C}$. On Solka Floc agar, the colonies reach their maximum size after 10 days of growth and show zones of
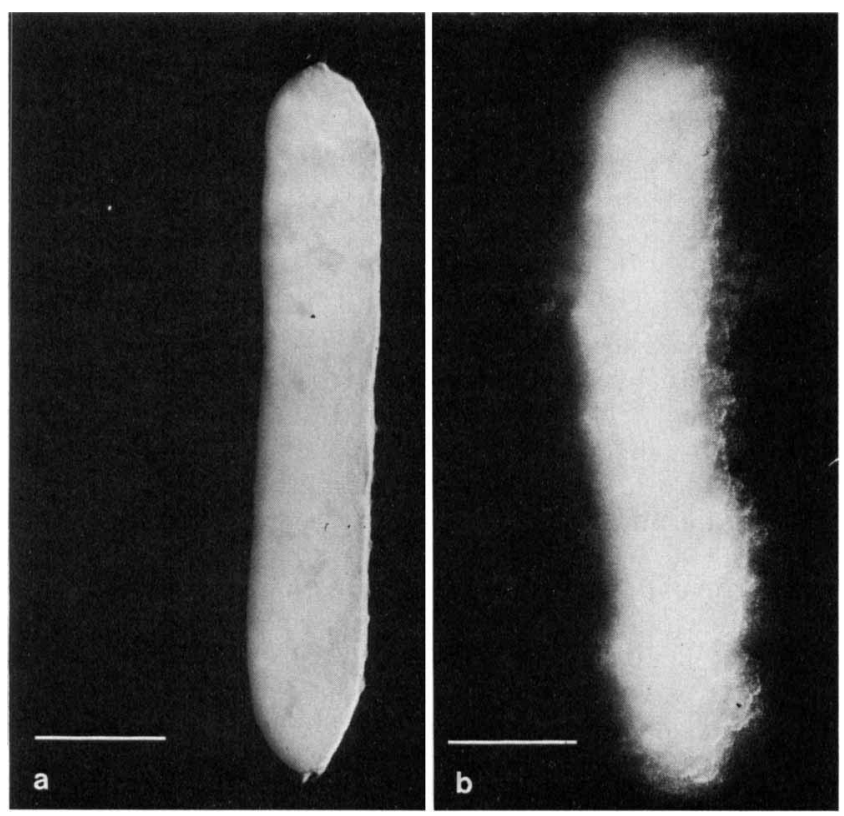

FIG. 1. Electron micrographs of Bacteroides cellulosolvens grown in cellobiose broth (a) and in cellulose (facial tissue) broth (b). Bars $=1 \mu \mathrm{m}$. cellulose clearing around the periphery of the colonies (Fig. 2) and in the agar below.

The temperature range for growth is 20 to $45.5^{\circ} \mathrm{C}$, with optimum growth at $42^{\circ} \mathrm{C}$. Facial tissue squares in basal broth are hydrolyzed within 21 days at $20^{\circ} \mathrm{C}$. A bright yellow sediment is produced in cellulose broth and cellobiose broth at growth temperatures between 20 and $40^{\circ} \mathrm{C}$, but not at temperatures above $40^{\circ} \mathrm{C} . \mathrm{B}$. cellulosolvens grows within a $\mathrm{pH}$ range of 5.7 to 8.0 , with optimum growth at $\mathrm{pH} 7.0$.

Anaerobic medium is required for growth. Of the substrates tested, only cellulose and cellobiose support growth. $B$. cellulosolvens ferments facial tissue, ball-milled pulp (Solka Floc), microcrystalline cellulose (Avicel), filter paper, absorbent cotton batting, cheesecloth, and steam-exploded aspen wood chips. No growth occurs in basal medium supplemented with adonitol, amygdalin, arabinose, dulcitol, esculin, erythritol, fructose, galactose, glucose, glycerol, glycogen, inositol, inulin, lactose, maltose, mannitol, mannose, melezitose, melibiose, raffinose, rhamnose, ribose, salicin, sorbitol, sorbose, starch, sucrose, trehalose, xylan, xylose, Casamino Acids, casein, chopped meat, milk, peptone, yeast extract, hippurate, lactate, pyruvate, or urea.

The following fermentation products from cellobiose broth are detected after 3 days of incubation (in millimoles per liter): $\mathrm{H}_{2}, 36.7 ; \mathrm{CO}_{2}, 30.0$; acetic acid, 17.1; ethanol, 8.6; and lactic acid, 1.2. The same products and yields are formed after 5 days from fermentation of cellulose. Acetylmethyl-

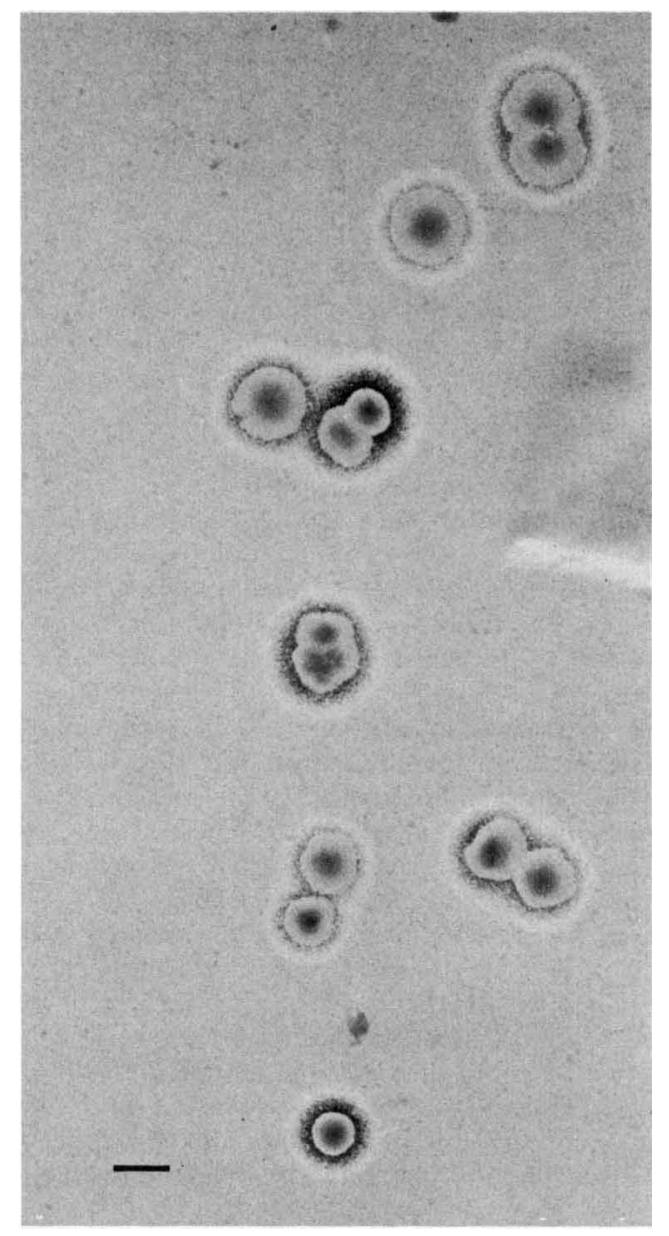

FIG. 2. Bacteroides cellulosolvens colony growth on Solka-Floc agar. Bar $=1 \mathrm{~mm}$. 
carbinol is produced; ammonia, indole, catalase, urease, and gelatinase are not. Sulfate and nitrate are not reduced.

The addition of bile ( $2 \%$ oxgall) to cellobiose broth inhibits growth, whereas Tween 80 , hemin, and vitamins $B_{12}$ and $K_{1}$ have no effect. Rumen fluid increases metabolite formation and growth. Unlike other species of Bacteroides $(2,17)$, the addition of complex substances to the basal medium does not influence the formation of fermentation products by $B$. cellulosolvens. Rumen fluid increases product yield but does not shift product ratios.

The DNA base composition is 43 mol\% guanine plus cytosine.

B. cellulosolvens type strain WM2 is deposited in the National Research Council of Canada culture collection as strain NRCC 2944.

Cellulolytic Bacteroides succinogenes differs from B. cellulosolvens by fermenting glucose, lactose, maltose, sorbose, starch, and trehalose, by consuming $\mathrm{CO}_{2}$ during cellulose fermentation, and by producing succinic acid (4).

Metabolically, B. cellulosolvens resembles Acetivibrio cellulolyticus. Both of these organisms were isolated from a methanogenic cellulose enrichment culture started from municipal sewage sludge. They use cellulose and cellobiose as substrates, and their major metabolic products are acetic acid, $\mathrm{CO}_{2}$, and $\mathrm{H}_{2}$ (14). However, $B$. cellulosolvens is morphologically distinct, and unlike $A$. cellulolyticus, it is nonmotile and unable to metabolize salicin.

Miyoshi (12) reported the isolation of 11 strains of anaerobic, cellulolytic, marine bacteria, all tentatively belonging to the genus Bacteroides. Six of these strains produced a yellow pigment, used cellulose and cellobiose as their sole carbon sources, and produced acetic acid as their major product. However, these strains differ from $B$. cellulosolvens in producing isobutyric acid, liquefying gelatin, and having an optimum growth temperature of $30^{\circ} \mathrm{C}$.

\section{ACKNOWLEDGMENTS}

The expert technical assistance of Lorraine Duchesne, Cheryl Meacher, and Elizabeth Pason is gratefully acknowledged. We thank A. W. Khan for the mixed culture of anaerobic bacteria from which $B$. cellulosolvens was isolated.

\section{LITERATURE CITED}

1. Ackman, R. G. 1972. Porous polymer bead packings and formic acid vapor in GLC of volatile fatty acids. J. Chromatogr. Sci. 10:560-565.
2. Chen, M., and M. J. Wolin. 1981. Influence of heme and vitamin $\mathrm{B}_{12}$ on growth and fermentations of Bacteroides species. $\mathrm{J}$. Bacteriol. 145:466-471.

3. Holdeman, L. V., E. P. Cato, and W. E. C. Moore (ed.). 1977. Anaerobe laboratory manual, 4th ed. Anaerobe Laboratory, Virginia Polytechnic Institute and State University, Blacksburg.

4. Holdeman, L. V., and W. E. C. Moore. 1974. Gram-negative anaerobic bacteria, p. 384-426. In R. E. Buchanan and N. E. Gibbons (ed.), Bergey's manual of determinative bacteriology, 8th ed. The Williams \& Wilkins Co., Baltimore.

5. Hungate, R. E. 1950. The anaerobic mesophilic cellulolytic bacteria. Bacteriol. Rev. 14:1-49.

6. Khan, A. W., and W. D. Murray. 1982. Isolation of a symbiotic culture of two species of bacteria capable of converting cellulose to ethanol and acetic acid. FEMS Microbiol. Lett. 13:377381.

7. Khan, A. W., T. M. Trottier, G. B. Patel, and S. M. Martin. 1979. Nutrient requirement for the degradation of cellulose to methane by a mixed population of anaerobes. J. Gen. Microbiol. 112:365-372.

8. Koransky, J. R., S. D. Allen, and V. R. Dowell. 1978. Use of ethanol for selective isolation of sporeforming microorganisms. Appl. Environ. Microbiol. 35:762-765.

9. Marmur, J. 1961. A procedure for the isolation of deoxyribonucleic acid from microorganisms. J. Mol. Biol. 3:208-218.

10. Mayfield, C. I., and W. E. Inniss. 1977. A rapid, simple method for staining bacterial flagella. Can. J. Microbiol. 23:1311-1313.

11. Miller, T. L., and M. J. Wolin. 1974. A serum bottle modification of the Hungate technique for cultivating obligate anaerobes. Appl. Microbiol. 27:985-987.

12. Miyoshi, H. 1978. Characterization of anaerobic cellulolytic bacteria isolated from marine environments. Bull. Jpn. Soc. Sci. Fish. 44:197-202.

13. Murray, W. D., A. W. Khan, and L. van den Berg. 1982. Clostridium saccharolyticum sp. nov., a saccharolytic species from sewage sludge. Int. J. Syst. Bacteriol. 32:132-135.

14. Patel, G. B., A. W. Khan, B. J. Agnew, and J. R. Colvin. 1980. Isolation and characterization of an anaerobic, cellulolytic microorganism, Acetivibrio cellulolyticus gen. nov., sp. nov. Int. J. Syst. Bacteriol. 30:179-185.

15. Ulitzer, S. 1972. Rapid determination of DNA base composition by ultraviolet spectroscopy. Biochim. Biophys. Acta 272:1-11.

16. van Huyssteen, J. J. 1967. Gas chromatographic separation of anaerobic digester gases using porous polymer. Water Res. $1: 237-242$.

17. Varel, V. H., and M. P. Bryant. 1974. Nutritional features of Bacteroides fragilis subsp. fragilis. Appl. Microbiol. 18:251257. 